\title{
A JUVENILE SAUROPODOMORPH TIBIA FROM THE 'BOTUCARAÍ HILL', LATE TRIASSIC OF SOUTHERN BRAZIL
}

\author{
FLÁVIO AUGUSTO PRETTO \\ Centro de Apoio à Pesquisa Paleontológica, Universidade Federal de Santa Maria, Rua Maximiliano Vizzotto, \\ 598, 97230-000, São João do Polêsine, RS, Brazil.flavio_pretto@yahoo.com.br
}

FÁBIO HIRATSUKA VEIGA

Programa de Pós-Graduação em Geociências, Setor de Paleovertebrados, Instituto de Geociências, UFRGS, Av. Bento Gonçalves, 9500 - Bloco J, Prédio 43127, Campus do Vale, Agronomia, 91540-000, Porto Alegre, RS, Brazil. fhveiga@gmail.com

MAX CARDOSO LANGER

Departamento de Biologia, Faculdade de Filosofia, Ciências e Letras de Ribeirão Preto, USP, Av. Bandeirantes, 3900, 14040-901, Ribeirão Preto, SP, Brazil.mclanger@ffclrp.usp.br

CESAR LEANDRO SCHULTZ

Setor de Paleovertebrados, Instituto de Geociências, UFRGS, Av. Bento Gonçalves, 9500 - Bloco J, Prédio 43127 , Campus do Vale, Agronomia, 91540-000, Porto Alegre, RS, Brazil. cesar.schultz@ufrgs.br

\begin{abstract}
The 'Botucaraí Hill' outcrop yielded a diverse Late Triassic vertebrate fauna, including several dinosaur remains, but most collected specimens are represented only by isolated bones. We present here a new dinosaur tibia from that site, particularly notable for its small size. Anatomical comparisons and a phylogenetic analysis support a sauropodomorph affinity for the specimen. In addition, histological analyses on transverse sections of the tibial shaft revealed a very thin bone wall, characterized by woven matrix with high vascularization, and the complete absence of lines of arrested growth (LAGs). These features suggest that the specimen was undergoing rapid and uninterrupted bone growth prior to death. Indeed, the small size of the specimen, the poor ossification of the bone extremities, and the absence of LAGs indicate that it represents a juvenile individual, as not previously recorded for the Brazilian Upper Triassic dinosaur fauna.
\end{abstract}

Key words: Dinosauria, Sauropodomorpha, bone histology, Upper Triassic, Candelária Sequence.

RESUMO - O afloramento do "Cerro Botucaraí" produziu uma fauna diversificada de vertebrados do Triássico Superior, incluindo vários restos de dinossauros, mas a maioria dos espécimes coletados é representada apenas por ossos isolados. Apresentamos aqui uma nova tíbia de dinossauro dessa localidade, particularmente notável por seu pequeno tamanho. Comparações anatômicas e uma análise filogenética suportam uma afinidade do espécime com Sauropodomorpha. Além disso, as análises histológicas em seções transversais do eixo tibial revelaram uma parede óssea muito fina, caracterizada por matriz tecidual com alta vascularização e a ausência completa de linhas de parada de crescimento (LAGs). Estas características sugerem que o espécime estava passando por um crescimento ósseo rápido e ininterrupto antes da morte. De fato, o pequeno tamanho do espécime, a fraca ossificação das extremidades ósseas e a ausência de LAGs indicam que a tíbia pertence a um indivíduo juvenil, algo ainda não registrado para a fauna de dinossauros do Triássico Superior do Brasil.

Palavras-chave: Dinosauria, Sauropodomorpha, histologia óssea, Triássico Superior, Sequência Candelária.

\section{INTRODUCTION}

The Upper Triassic Candelária Sequence of southern Brazil yields an important record of the early stages of dinosaur radiation, including some of the oldest dinosaurs. Reported taxa include the herrerasaurid Staurikosaurus pricei proposed by Colbert (1970) and the sauropodomorphs Saturnalia tupiniquim and Pampadromaeus barberenai described by Langer et al. (1999) and Cabreira et al. (2011), respectively, in addition to other reported undetermined or fragmentary remains (Müller et al., 2014, 2016; Pretto et al., 2015). These dinosaurs are part of a faunal assemblage coeval to that of the Ischigualasto Formation of northwestern Argentina, mostly due to the occurrence of the hyperodapedontid rhynchosaurs that characterize the Hyperodapedon Assemblage Zone (Schultz et al., 2000; Langer, 2005a,b). A slightly younger fauna, correlated to the Argentinean Los Colorados Formation, is recovered from the upper portions of the Candelária Sequence. Reported dinosauriforms include the silesaurid Sacisaurus agudoensis Ferigolo \& Langer, 2007, the putative 
theropod Guaibasaurus candelariensis Bonaparte, Ferigolo \& Ribeiro, 1999, and the sauropodomorph Unaysaurus tolentinoi Leal et al., 2004, apart from other fragmentary or not yet described materials (Bittencourt et al., 2012a,b; Müller et al., 2015).

Although less abundant than that of Argentina, the Brazilian Late Triassic dinosaur record is increasing due to the intensification of fieldworks and the reassessment of previous collections. In this context, even fragmentary materials are important, allowing a more detailed understanding of the paleofaunas and their morphological diversity. In this paper, we increase the dinosaur record of the upper Candelária Sequence with a new dinosaur tibia from the 'Botucaraí Hill' outcrop, Rio Grande do Sul, Brazil. Although fragmentary, the specimen is remarkable for its significantly smaller size compared to that of coeval Brazilian dinosaurs. Along with a comparative description, we provide histological data, in order to assess the ontogenetic stage of the individual.

\section{GEOLOGICAL SETTING}

The Botucaraí Hill site is one of a series of outcrops exposed at cuts along the margins of BR 287 road, in the outskirts of Candelária, Rio Grande do Sul (RS), Brazil (Bittencourt et $a l ., 2012 b)$. The locality from which the new specimen was collected shows the typical lithology of the upper portions of the Candelária Sequence of the Santa Maria Supersequence (Zerfass et al., 2003; Horn et al., 2014); composed mostly of pink thin sandstones deposited in a fluvial context. The section shows occasional rithmic intervals with millimetric mudstone layers, as well as occasional mud intraclasts. The fossil record of the locality includes the dicynodont Jachaleria candelariensis Araújo \& Gonzaga, 1980, the prozostrodontian cynodont Botucaraitherium belarminoi Soares, Martinelli \& Oliveira, 2014, as well as an indeterminate phytosaur, a stereospondyl amphibian, and several isolated archosaur teeth (Araújo \& Gonzaga, 1980; Dornelles, 1990; Kischlat \& Lucas, 2003; Dias-da-Silva et al., 2009; Soares et al., 2014). An isolated tooth referred to Riograndia guaibensis was also reported by Soares et al. (2011) from the upper portions of the outcrop. The fossil occurrences, as well as the lateral correlation to nearby outcrops, suggest that the site is representative of the Riograndia Assemblage Zone (Soares et al., 2011).

\section{MATERIAL AND METHODS}

MMACR-PV-028-T consists of a single tibia, collected by the team of Museu Municipal Aristides Carlos Rodrigues (MMACR), led by Mr. Belarmino Stefanello. The material underwent some mechanical preparation, using small chisels, and fractures were consolidated using cyanoacrylatebased adhesives. The anatomical description followed the nomenclature proposed by Weishampel et al. (2004). The phylogenetic relationships of MMACR-PV-028-T were assessed based on the dataset of Bittencourt et al. (2014). A total of thirteen characters were scored (Appendix 1), eleven for the tibia and two inferred for the astragalus based on tibial traits. No other changes were conducted on the original character matrix, which was analyzed with the software TNT 1.1 (Goloboff et al., 2008) under 'Traditional search' with 10,000 replications of Wagner trees (with random addition sequence) and random seed of 0 . The tree bisection reconnection (TBR) algorithm was employed with 20 trees saved per replication. No characters were ordered.

For the osteohistology analyses, a midshaft section of the bone (Figure 1) was extracted and embedded in clear epoxy resin. The sample was thin sectioned following the methods adopted by Chinsamy \& Raath (1992). Imaging and measurements were made using a petrographic polarized microscope Carl Zeiss Microscope $\mathrm{GmbH}$ and photographs were obtained using an AxioCam ERc 5s microscope camera. Cortical thickness was calculated as the ratio between the cross sectional bone wall thickness and the cross sectional radius of the bone, and expressed as a percentage. Employed histological terminology follows Francillon-Vieillot et al. (1990), Reid (1996), and Starck \& Chinsamy (2002).

\section{RESULTS}

\section{Description}

The tibia (Figure 1) is $110 \mathrm{~mm}$ long (proximodistally) and is slightly damaged by superficial fractures. More significant taphonomic damages are observed in the craniomedial surface of the proximal quarter of the bone, where the outer structure collapsed resulting in a conspicuous depression on the medial surface. The proximal articulation of the tibia is flat, with a triangular outline (Figure 1E). This morphology differs from that of most dinosauriform tibiae, but resembles that of a particular specimen (ZPAL Ab III 460/3) of Silesaurus opolensis Dzik, 2003, which is itself quite distinct from other tibiae referred to that taxon. It is possible, however, that the proximal end of MMACR-PV-028-T is distorted, following the deformation on its medial margin. The lateral (fibular) condyle is more cranially set (Figures 1B, E) than the medial condyle, as in early sauropodomorphs, ornithischians (Langer \& Benton, 2006), Marasuchus lilloensis (Romer, 1972) and Pseudolagosuchus major Arcucci, 1987. This morphology contrasts with that observed in lagerpetids, many silesaurids (e.g. Asilisaurus kongwe Nesbitt et al., 2010, Silesaurus opolensis, and Sacisaurus agudoensis), herrerasaurids, and theropods, in which both condyles are positioned at the caudal margin of the proximal end of the tibia (Dzik, 2003; Langer \& Benton, 2006; Nesbitt et al., 2010; Langer \& Ferigolo, 2013). A shallow intercondylar notch (Figures 1C, E) separates both condyles of MMACRPV-028-T caudally. The cnemial crest is poorly developed (Figures 1A-B, E), differing from that of most dinosaurs and resembling more that of other dinosauromorphs (Langer \& Benton, 2006). It is marked by a very faint transverse groove that is continuous to an equally faint incisura tibialis on the lateral surface of the bone. The cnemial crest seems to have been directed craniolaterally, but this may be an artifact of preservation. In lateral view, it does not surpass the height of 

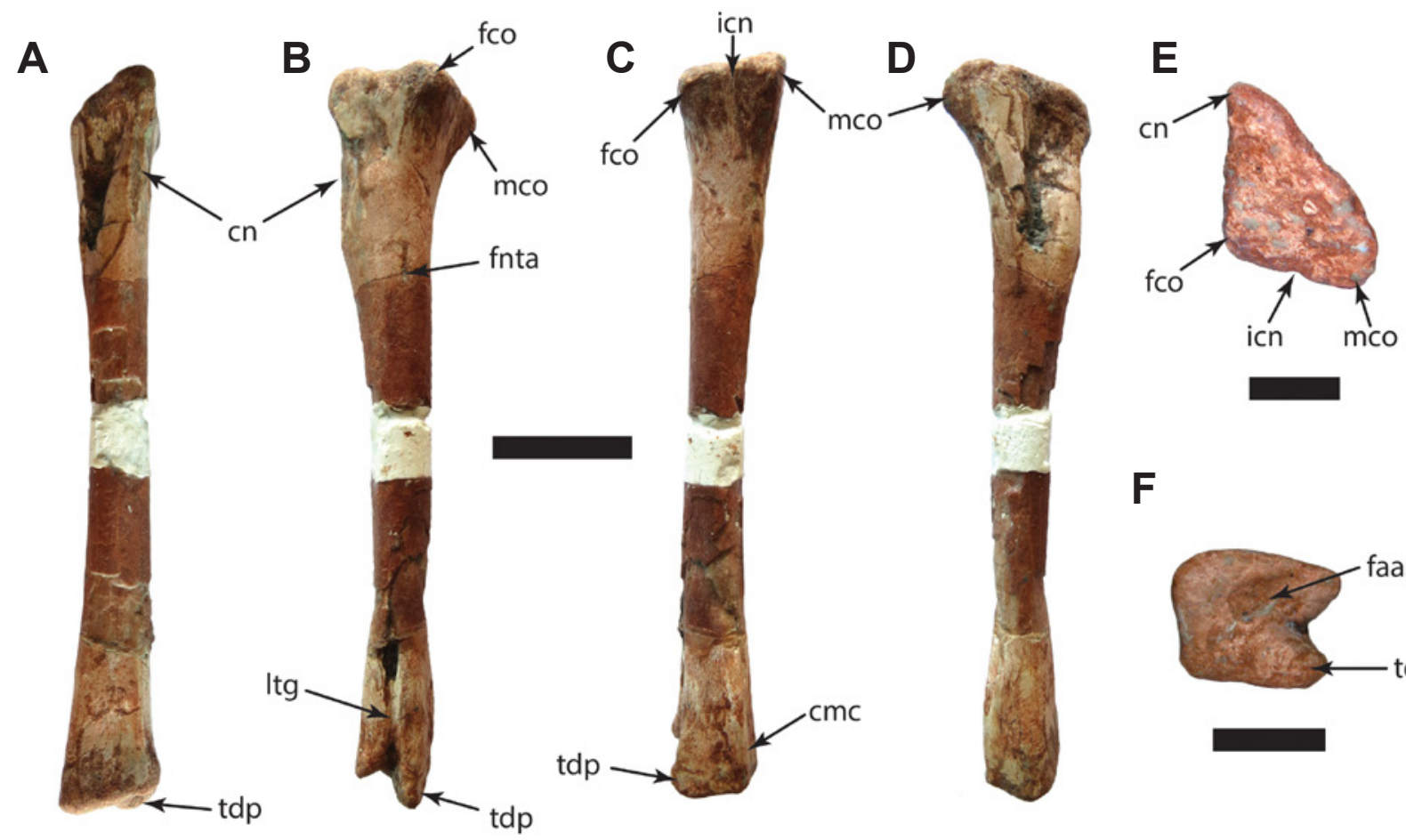

$\mathbf{F}$

Figure 1. MMACR-PV-028-T, left tibia in cranial (A), lateral (B), caudal (C), medial (D), proximal (E), and distal (F) views. White area corresponds to the thin sectioned portion. Abbreviations: cmc, caudomedial crest; cn, cnemial crest; faap, articular facet for the astragalar ascending process; fco, fibular condyle; fnta, foramen for the nutritive tibial artery; icn, intercondylar notch; Itg, lateral tibial groove; mco, medial condyle; tdp, tibial descending process. Scale bars: $A-D=20 \mathrm{~mm} ; E-F=10 \mathrm{~mm}$.

the proximal condyles. It neither extends far distally, being restricted to the proximal quarter of the tibial proximodistal length. The lateral margin of the fibular condyle is rounded (Figure 1E). There is no evidence of a fibular crest on the lateral surface of the tibia, differing from the condition seen in most early dinosaurs. A distinct foramen perforates the lateral surface of the bone (Figure 1B), probably related to the nutritive tibial artery (Baumel, 1993; Langer, 2003). It is located ventral to the fibular condyle, at the level of distalmost extent of the cnemial crest. The tibial shaft is significantly narrower than the proximal extremity of the bone, and is circular in cross-section. Its mediolateral width increases slightly towards the distal end, resulting in a sub-rectangular distal outline (Figure 1F), as seen in early sauropodomorphs such as Eoraptor lunensis Sereno et al., 1993, Panphagia protos Martínez \& Alcober, 2009, or Saturnalia tupiniquim (see Langer, 2003; Martinez \& Alcober, 2009; Sereno et al., 2013). The craniolateral corner of the distal end of the tibia is sloped proximally, forming an articular surface that accommodated the ascending process of the astragalus (Figure 1F). Conversely, the caudolateral portion of that articulation forms a distinct flange, the tibial descending process (Figures 1B-C, F), that caudally covered the ascending process of the astragalus. This process is slightly projected laterally, possibly touching, although not caudally covering, the fibula when articulated. A faint depression separates the caudal descending process from the articular facet for the ascending process of the astragalus. This is contiguous to a marked groove at the lateral surface of the tibial shaft, the proximal extension of which is obliterated by a fractured portion of the bone (Figure 1B). In caudal view, the distal portion of the tibia bears a sharp crest (Figure 1C) that extends along the caudomedial corner of the bone, from the distal extremity along one-fifth of the total tibial length.

\section{Histology}

The transverse section of the tibial mid-shaft (Figure 2) shows a large free medullary cavity, with a well-defined boundary, surrounded by a narrow cortex with 1.4 to $1.8 \mathrm{~mm}$ in thickness (about $34 \%$ of the relative radius of the bone). The cortex is composed of a fibrolamellar bone tissue of woven-fibered bone associated with primary osteons (Figures $3 \mathrm{~A}-\mathrm{D})$. The bone tissue is highly vascularized, and globular osteocyte lacunae are randomly distributed among the primary osteons. In the inner cortex, the primary osteons are large and longitudinally oriented, with few radial and circumferential anastomoses. The outer cortex bears more circumferential anastomoses, with the primary osteons forming a laminar arrangement (Figure 3B). No decrease in vascularization is seen towards the external surface of the cortex. Growth marks [lines of arrested growth (LAGs), or annuli] are absent. There are also no secondary osteons, and therefore, no indication of secondary bone reconstruction.

\section{Phylogenetic analysis}

The search resulted in 27 most parsimonious trees (Consistency Index $=0.44$; Retention Index $=0.62$ ) of 781 steps, the strict consensus of which (Figure 4A) shows 


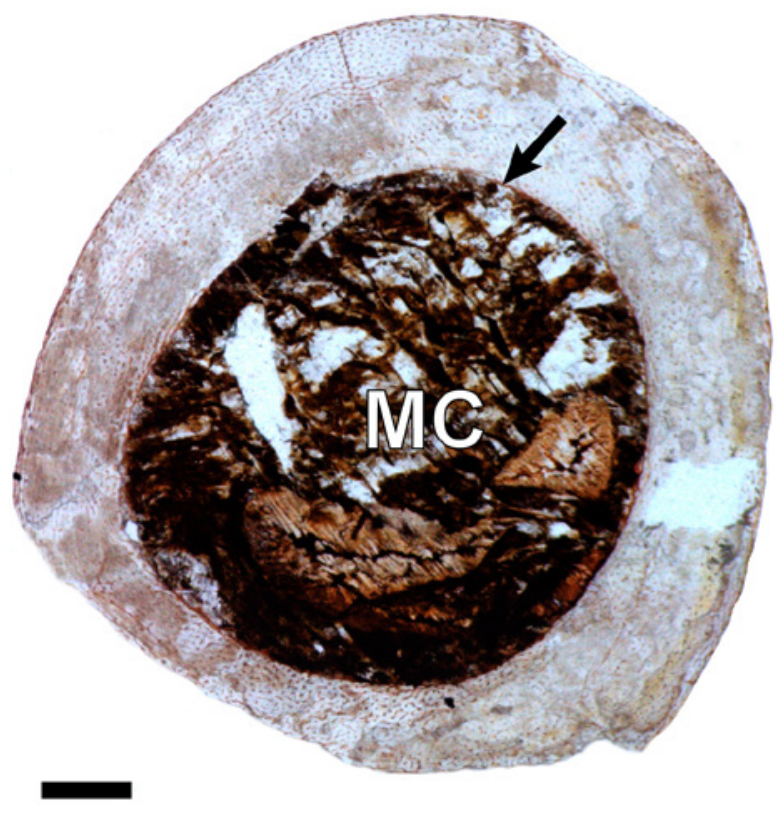

Figure 2. General view of the complete cross-section of the tibia of MMACR-PV-028-T at midshaft. The medullary cavity (MC) has a welldefined boundary (black arrow). Scale bar $=1 \mathrm{~mm}$. several collapsed nodes, as in the original analysis performed by Bittencourt et al. (2014). This was mostly caused by the unstable positions of Pseudolagosuchus major and Guaibasaurus candelariensis, as identified by the application of IterPCR method (Pol \& Escapa, 2009). Pruning those taxa, as performed by Bittencourt et al. (2014), resulted in a better resolved reduced consensus tree (Figure 4B). In both trees, MMACR-PV-028-T is well nested within Sauropodomorpha, closely related to Plateosaurus engelhardti von Meyer, 1837.

\section{DISCUSSION AND CONCLUSION}

The phylogenetic analysis recovered MMACR-PV-028-T within Sauropodomorpha. Yet, although some morphological aspects of the specimen are, indeed, reminiscent of the condition seen in early sauropodomorphs (e.g. the cranially set fibular condyle and the sub-quadrangular shape of the distal tibia), these traits also have a broader distribution among dinosauriforms. The faint cnemial crest resembles that of early dinosauromorphs (Langer \& Benton, 2006), but it is possible that it results from the poor ossification of the extremities, as expected for a not fully ontogenetically developed individual. This hypothesis is consistent with

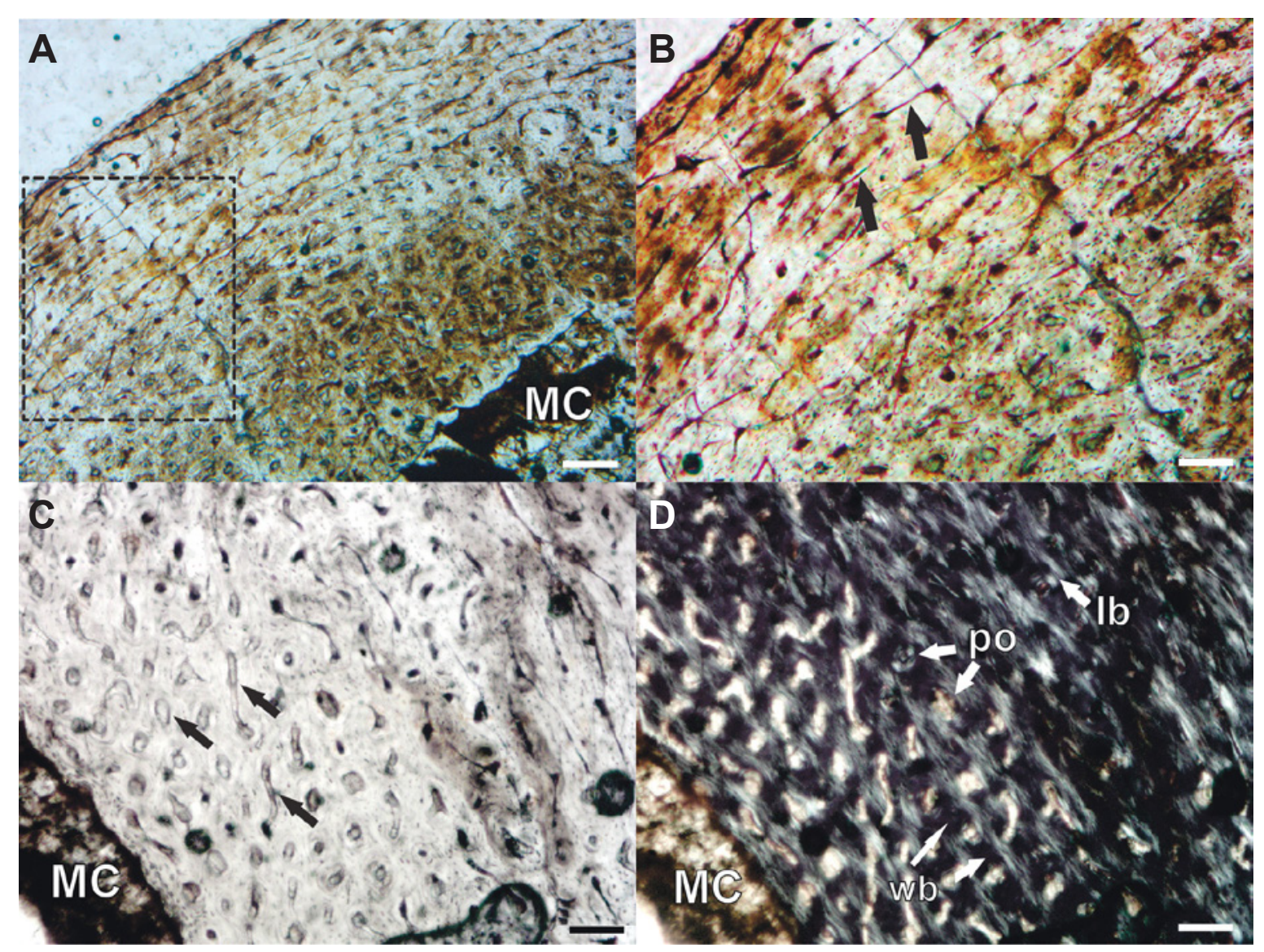

Figure 3. Transverse sections showing the bone histology of the tibia of MMACR-PV-028-T. A, general view of the cortex showing abundant vascular canals. B, higher magnification of the cortex (box inset in A) showing primary osteons with circumferential anastomoses (black arrows). C, perimedullary region with enlarged primary osteons (black arrows). D, same section shown in C under polarized light. Note the deposition of lamellar bone around the primary osteons. Abbreviations: mc, medullary cavity; lb, lamellar bone; po, primary osteons; wb, woven bone. Scale bars: $A=0,2 \mathrm{~mm}$; $B-D=0,1 \mathrm{~mm}$. 
the faintness of both the notch that separates the fibular and medial condyles caudally and the proximal transverse groove of the tibia. This poor ossification may also explain the absence of a fibular crest in the lateral surface of the tibia, a structure typically present among early dinosaurs, including several early sauropodomorphs. In the sampled OTUs of our phylogenetic analysis, a fibular crest is also absent only in Plateosaurus engelhardti. This surely helped to enforce their close affinity (Figure 4), which is probably not so strongly constrained.

The sub-quadrangular distal articulation of the tibia of our specimen is reminiscent of that seen in early sauropodomorphs, including Eoraptor lunensis, Panphagia protos, Saturnalia tupiniquim, Adeopapposaurus mognai Martínez, 2009, Unaysaurus tolentinoi, Efraasia minor (von Huene, 19071908), and Plateosaurus engelhardti (Langer, 2003; Leal et al., 2004; Langer \& Benton, 2006; Martínez, 2009; Martinez \& Alcober, 2009; Sereno et al., 2013). Among the sampled OTUs, the tibia of MMACR-PV-028-T resembles that of many early dinosaurs (e.g. Herrerasaurus ischigualastensis Reig, 1963, S. tupiniquim, P. protos) for its sub-quadrangular shape (Novas, 1993; Langer, 2003; Martinez \& Alcober, 2009). Many dinosauriforms, including some early dinosaurs (e.g. Asilisaurus kongwe, Silesaurus opolensis, Marasuchus lilloensis, Staurikosaurus pricei Colbert, 1970, Tawa hallae Nesbitt et al., 2009), bear an elliptical to sub-circular distal tibia outline (Sereno \& Arcucci, 1994; Dzik, 2003; Langer
\& Benton, 2006; Bittencourt \& Kellner, 2009; Nesbitt et al., $2009,2010)$. However, it is noteworthy that, additional to the subquadrangular shape, the tibia of MMACR-PV-028-T bears a subtle mediolateral expansion, similar to the observed in Plateosaurus engelhardti. Notwithstanding, the tibia of MMACR-PV-028-T is not expanded at the same extend as in Plateosaurus engelhardti, being rather an intermediate between the condition seen in that taxon and early dinosaurs. Early ornithischians (e.g. Lesothosaurus diagnosticus Galton, 1978 and Scelidosaurus harrisonii Owen, 1861) and theropods (e.g. Liliensternus liliensterni (Huene, 1934) and Syntarsus rhodesiensis Raath, 1969) also have a transversely wider distal tibia articulation, but much more marked than in $P$. engelhardti and MMACR-PV-028-T (Langer \& Benton, 2006).

The analysis of the microstructure of MMACR-PV-028-T revealed a highly vascularized, uninterrupted fibrolamellar bone tissue with a predominantly laminar arrangement, which is characteristic of rapid bone deposition and growth (Amprino, 1947; Francillon-Vieillot et al., 1990; ChinsamyTuran, 2005). This tissue and the vascular arrangement pattern resemble those of other dinosaurs (Padian et al., 2001; Chinsamy-Turan, 2005) including sauropodomorphs, such as Massospondylus carinatus Owen, 1854, Thecodontosaurus antiquus Morris, 1843, Plateosaurus engelhardti, Saturnalia tupiniquim, and Mussaurus patagonicus Bonaparte \& Vince, 1979 (Chinsamy, 1993a; Klein \& Sander, 2007; Stein \& Langer, 2009; Cerda et al., 2014). Some of these studies

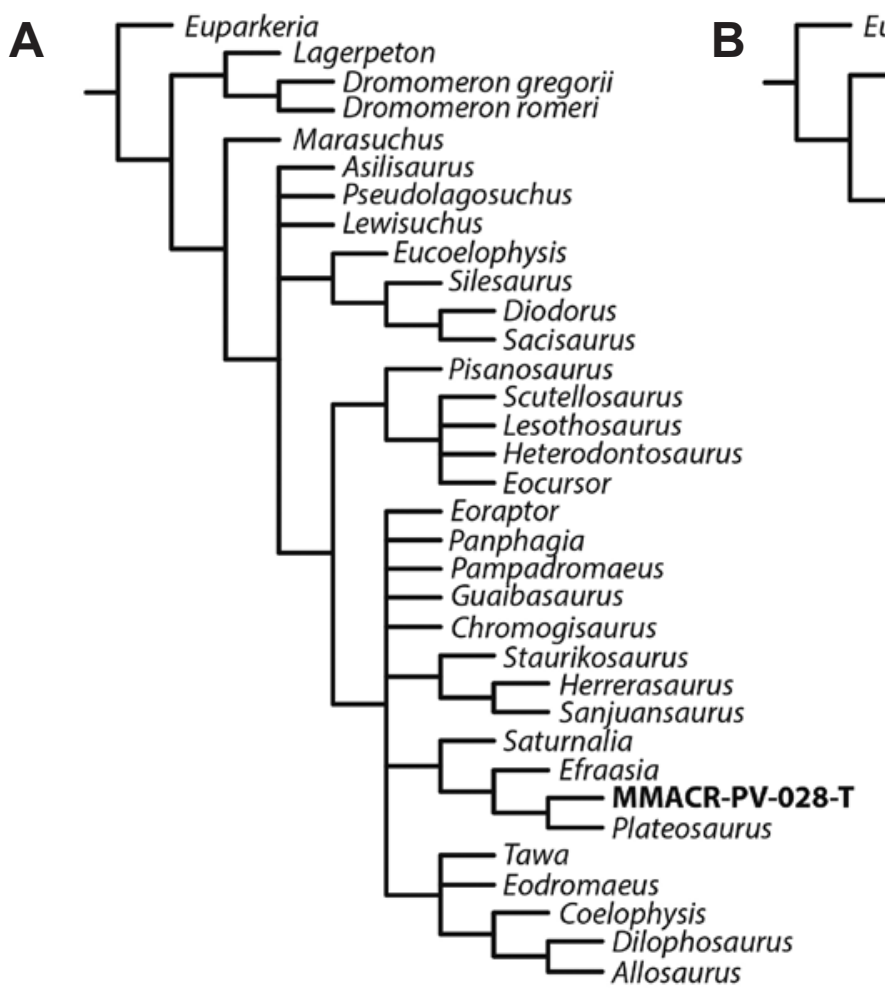

Euparkeria
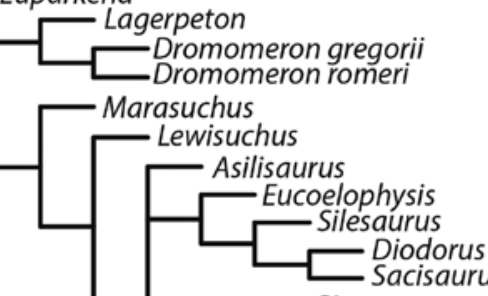

- Pisanosaurus
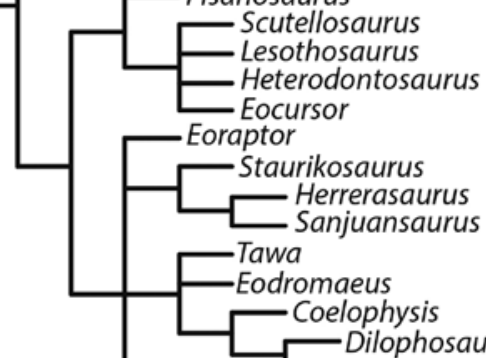

Dilophosaurus
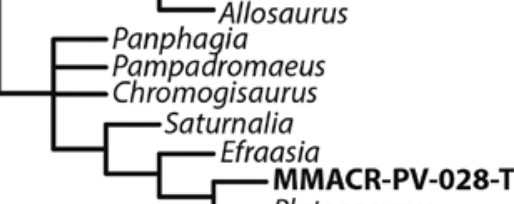

Plateosaurus

Figure 4. Phylogenetic relationships of MMACR-PV-028-T, based on the data matrix of Bittencourt et al. (2014). A, strict consensus of the 27 most parsimonious trees (tree length $=781 ; \mathrm{Cl}=0.44 ; \mathrm{RI}=0.62$ ). B, reduced consensus derived from the application of IterPCR method of Pol \& Escapa (2009), resulting in the exclusion of Pseudolagosuchus major and Guaibasaurus candelariensis. 
on early sauropodomorph histology also reported a cortex cyclically interrupted by growth marks (LAGs), which indicate a periodical reduction in bone growth rate, probably due to seasonal stress (Padian \& Lamm, 2013).

The bone cortex of MMACR-PV-028-T, in contrast, lacks growth marks. Indeed, it resembles specimens of Mussaurus patagonicus described by Cerda et al. (2014). Those authors attributed the absence of LAGs to the ontogenetic stage of the sample and assumed the specimens to consist of small (femur length between 111-120 mm), juvenile individuals, which died before the first year of life. Such interpretation also applies to MMACR-PV-028-T. Assuming the seasonality of growth marks, a short lifespan would prevent the formation of the first LAG, which should appear only in older immature and adult individuals. Additional to the absence of LAGs, other histological features support the hypothesis of the early ontogenetic stage of MMACRPV-028-T. The woven-fibered bone matrix is indicative of young age, as it represents the earliest stage of fibrolamellar bone formation; commonly found in immature animals with high growth rates (Chinsamy-Turan, 2005; Padian \& Lamm, 2013). Additionally, there is no decrease in vascularization towards the outer cortex, which suggests that the specimen was growing at fast rate prior to death. In general, vascularization and growth rate decrease throughout life (Chinsamy, 1993a; Curry, 1999; Horner et al., 2000). The absence of remodeling processes and secondary osteons is also typical of young individuals. The replacement of primary bone by remodeling and the deposition of secondary bone tend to increase with age, as well as the density of secondary osteons (Klein \& Sander, 2007, 2008). Finally, the specimen lacks an inner circumferential layer (ICL). The ICL is an endosteal deposition of lamellar bone that occurs as a result of the enlargement and remodeling of the medullary cavity. It is reported in several dinosaurs (see Chinsamy-Turan, 2005) and indicates ontogenetic maturity (Reid, 1997).

The young ontogenetic stage of MMACR-PV-028-T, supported by its small size and histological features, can explain the faint ossification of the proximal end of the tibia, and would also be responsible for the lack of some osteological traits, such as the fibular crest. Additionally, recognized as such, MMACR-PV-028-T is the first juvenile dinosaur specimen reported for the Brazilian Triassic.

\section{ACKNOWLEDGEMENTS}

We thank C.N. Rodrigues (curator of MMACR), who made the specimen available for study on the specimen, and B. Stefanello, who discovered the material. We are also thankful to L.A. Hartmann, I. Cerda, and an anonymous reviewer, for helpful comments on the manuscript. This study was partially funded by grants provided by Conselho Nacional de Desenvolvimento Científico e Tecnológico $(\mathrm{CNPq})$ to FAP (process 140743/2012-0) and Fundação de Amparo à Pesquisa do Estado de São Paulo (FAPESP) to MCL (process number 2014/03825-3).

\section{REFERENCES}

Amprino, R. 1947. La structure du tissu osseux envisagée comme expression de différences dans la vitesse de l'accroissement. Archives de Biologie, 58:315-330.

Araújo, D.C. \& Gonzaga, T.D. 1980. Uma nova espécie de Jachaleria (Therapsida, Dicynodontia) do Triássico do Brasil. In: CONGRESO ARGENTINO DE PALEONTOLOGÍA Y BIOSTRATIGRAFÍA, 2; CONGRESSO LATINOAMERICANO DE PALEONTOlOGíA, 1, 1980. Actas, Buenos Aires, p. 159-174.

Arcucci, A.B. 1987. Un nuevo Lagosuchidae (ThecodontiaPseudosuchia) de la fauna de Los Chañares (Edad Reptil Chanarense, Triasico Medio), La Rioja, Argentina. Ameghiniana, 24:89-94.

Baumel, J.J. 1993. Handbook of Avian Anatomy: Nomina Anatomica Avium. Cambridge, Nuttall Ornithological Club, 779 p. (Publications 23).

Bittencourt, J. de S.; Arcucci, A.B.; Marsicano, C.A. \& Langer, M.C. 2014. Osteology of the Middle Triassic archosaur Lewisuchus admixtus Romer (Chañares Formation, Argentina), its inclusivity, and relationships amongst early dinosauromorphs. Journal of Systematic Palaeontology, 13:189-219. doi:10.1080/1477201 9.2013.878758

Bittencourt, J. de S.; da Rosa, Á.A.S.; Schultz, C.L. \& Langer.M.C. 2012a. Dinosaur remains from the "Botucaraí Hill" (Caturrita Formation), Late Triassic of south Brazil, and their stratigraphic context. Historical Biology, 25:81-93. doi:10.1080/08912963 .2012 .694881

Bittencourt, J. de S. \& Kellner, A.W.A. 2009. The anatomy and phylogenetic position of the Triassic dinosaur Staurikosaurus pricei Colbert, 1970. Zootaxa, 2079:1-56.

Bittencourt, J. de S.; Leal, L.A.; Langer, M.C. \& Azevedo, S.A.K. 2012 b. An additional basal sauropodomorph specimen from the Upper Triassic Caturrita Formation, southern Brazil, with comments on the biogeography of plateosaurids. Alcheringa, 36:269-278. doi:10.1080/03115518.2012.634111

Bonaparte, J.F.; Ferigolo, J. \& Ribeiro, A.M. 1999. A new Early Late Triassic saurischian dinosaur from Rio Grande Do Sul State, Brazil. In: Y. Tomida; T.H. Rich \& P. Vickers-Rich (eds.) Proceedings of the Second Gondwanan Dinosaur Symposium, Tokyo, National Science Museum of Tokyo, p. 89-109 (Monographs 15).

Cabreira, S.F.; Schultz, C.L.; Bittencourt, J. de S.; Soares, M.B.; Fortier, D.C.; Silva, L.R \& Langer, M.C. 2011. New stemsauropodomorph (Dinosauria, Saurischia) from the Triassic of Brazil. Naturwissenschaften, 98:1035-1040. doi:10.1007/ s00114-011-0858-0

Cerda, I.A.; Pol, D. \& Chinsamy, A. 2014. Osteohistological insight into the early stages of growth in Mussaurus patagonicus (Dinosauria, Sauropodomorpha). Historical Biology, 26:110 121. doi:10.1080/08912963.2012.763119

Chinsamy, A. 1993a. Bone histology and growth trajectory of the prosauropod dinosaur Massospondylus carinatus Owen. Modern Geology, 18:319-329.

Chinsamy, A. \& Raath. M.A. 1992. Preparation of fossil bone for histological examination. Palaeontologia Africana, 29:3-44.

Chinsamy-Turan, A. 2005. The Microstructure of Dinosaur Bone. Baltimore, Johns Hopkins University Press, 195 p.

Colbert, E. H. 1970. A saurischian dinosaur from the Triassic of Brazil. American Museum Novitates, 2405:1-60. 
Curry, K.A. 1999. Ontogenetic histology of Apatosaurus (Dinosauria: Sauropoda): new insights on growth rates and longevity. Journal of Vertebrate Paleontology, 19:654-665. doi:10.1080/0272463 4.1999.10011179

Dias-da-Silva, S.; Dias, E.V. \& Schultz, C.L. 2009. First record of stereospondyls (Tetrapoda, Temnospondyli) in the Upper Triassic of Southern Brazil. Gondwana Research, 15: 131-136. doi:10.1016/j.gr.2008.07.002

Dornelles, J.E.F. 1990. Registro sobre a ocorrência de dentes de um arcossáurio para a Formação Caturrita, Triássico Superior do Rio Grande do Sul. Ciência \& Natura, 12: 99-101.

Dzik, J. 2003. A beaked herbivorous archosaur with dinosaur affinities from the Early Late Triassic of Poland. Journal of Vertebrate Paleontology, 23:556-574. doi:10.1671/A1097

Ferigolo, J. \& Langer, M.C. 2007. A Late Triassic dinosauriform from south Brazil and the origin of the ornithischian predentary bone. Historical Biology, 19:23-33. doi:10.1080/08912960600845767

Francillon-Vieillot, H.; de Buffrénil, V.; Castanet, J.; Geraudie, J.; Meunier, F.J.; Sire, J.Y.; Zylberberg, L. \& de Ricqlès, A. 1990. Microstructure and mineralization of vertebrate skeletal tissues. In: J.G. Carter (ed.) Skeletal Biomineralization: Patterns, Processes and Evolutionary Trends, Van Nostrand Reinhold, p. 471-548.

Goloboff, P.A.; Farris, J.S. \& Nixon, K.C. 2008. TNT, a free program for phylogenetic analysis. Cladistics, 24:774-786. doi:10.1111/ j.1096-0031.2008.00217.x

Horn, B.L.D.; Melo, T.P.; Schultz, C.L.; Philipp, R.P.; Kloss, H.P. \& Goldberg, K. 2014. A new third-order sequence stratigraphic framework applied to the Triassic of the Paraná Basin, Rio Grande do Sul, Brazil, based on structural, stratigraphic and paleontological data. Journal of South American Earth Sciences, 55:123-132. doi:10.1016/j.jsames.2014.07.007

Horner, J.R.; Ricqlès A. de \& Padian, K. 2000. Long bone histology of the hadrosaurid dinosaur Maiasaura peeblesorum: growth dynamics and physiology based on an ontogenetic series of skeletal elements. Journal of Vertebrate Paleontology, 20:109-123. doi:10.1671/0272-4634(2000)020[0115:LBHOT H]2.0.CO;2

Kischlat, E.E.; \& Lucas, S.G. 2003. A phytosaur from the Upper Triassic of Brazil. Journal of Vertebrate Paleontology, 23:464-467. doi:10.1671/0272-4634(2003)023[0464:APFTU T]2.0.CO;2

Klein, N. \& Sander, P.M. 2007. Bone histology and growth of the prosauropod Plateosaurus engelhardti Meyer, 1837 from the Norian bonebeds of Trossingen (Germany) and Frick (Switzerland). Special Papers in Palaeontology, 77:169-206.

Klein, N. \& Sander, P.M. 2008. Ontogenetic stages in the long bone histology of sauropod dinosaurs. Paleobiology, 34:247-263. doi:10.1666/0094-8373(2008)034[0247:OSITLB]2.0.CO;2

Langer, M.C. 2003. The pelvic and hind limb anatomy of the stemsauropodomorph Saturnalia tupiniquim (Late Triassic, Brazil). PaleoBios, 23:1-40.

Langer, M.C. 2005a. Studies on continental Late Triassic tetrapod biochronology. I. The type locality of Saturnalia tupiniquim and the faunal succession in south Brazil. Journal of South American Earth Sciences, 19:205-218. doi:10.1016/j.jsames.2005.04.003

Langer, M.C. 2005b. Studies on continental Late Triassic tetrapod biochronology. II. The Ischigualastian and a Carnian global correlation. Journal of South American Earth Sciences, 19:219239. doi:10.1016/j.jsames.2005.04.002

Langer, M.C.; Abdala, F.; Richter, M. \& Benton, M.J. 1999. A sauropodomorph dinosaur from the Upper Triassic (Carnian) of southern Brazil. Comptes Rendus de l'Academie Des Sciences Paris, 329:511-517.

Langer, M.C. \& Benton, M.J. 2006. Early dinosaurs: a phylogenetic study. Journal of Systematic Palaeontology, 4:309-358. doi:10.1017/S1477201906001970

Langer, M.C. \& Ferigolo, J. 2013. The Late Triassic dinosauromorph Sacisaurus agudoensis (Caturrita Formation; Rio Grande do Sul, Brazil): anatomy and affinities. Geological Society, London, Special Publications, 379:353-392. doi: 10.1144/SP379.16

Leal, L.A.; Azevedo, S.A.K.; Kellner, A.W.A. \& da Rosa, Á.A.S. 2004. A new early dinosaur (Sauropodomorpha) from the Caturrita Formation (Late Triassic), Paraná Basin, Brazil. Zootaxa, 690:1-24.

Martínez, R.N. 2009. Adeopapposaurus mognai, gen. et sp. nov. (Dinosauria: Sauropodomorpha), with comments on adaptations of basal Sauropodomorpha. Journal of Vertebrate Paleontology, 29:142-164. doi:10.1671/039.029.0102

Martínez, R.N. \& Alcober, O.A. 2009. A Basal Sauropodomorph (Dinosauria: Saurischia) from the Ischigualasto Formation (Triassic, Carnian) and the Early Evolution of Sauropodomorpha. PLoS ONE, 4:e4397. doi:10.1371/journal.pone.0004397

Müller, R.T.; da Rosa, Á.A.S.; da Silva, L.R.; Aires, A.S.S.; Pacheco, C.P.; Pavanatto, A.E.B. \& Dias-da-Silva, S. 2015. Wachholz, a new exquisite dinosaur-bearing fossiliferous site from the Upper Triassic of southern Brazil. Journal of South American Earth Sciences, 61:120-128. doi:10.1016/j.jsames.2014.10.009

Müller, R.T.; Langer, M.C.; Aires, A.S.S. \& Dias-da-Silva, S. 2014. New dinosauriform (Ornithodira, Dinosauromorpha) record from the Late Triassic of Southern Brazil. Paleontological Research, 18:118-121. doi:10.2517/2014PR012

Müller, R.T.; Langer, M.C.; Cabreira, S.F. \& Dias-da-Silva, S. 2016. The femoral anatomy of Pampadromaeus barberenai based on a new specimen from the Upper Triassic of Brazil. Historical Biology, 28:656-665. doi:10.1080/08912963.2015.1004329

Nesbitt, S.J.; Sidor, C.A.; Irmis, R.B.; Angielczyk, K.D.; Smith, R.M.H. \& Tsuji, L.A. 2010. Ecologically distinct dinosaurian sister group shows early diversification of Ornithodira. Nature, 464:95-98. doi:10.1038/nature08718

Nesbitt, S.J.; Smith, N.D.; Irmis, R.B.; Turner, A.H.; Downs, A. \& Norell. M.A. 2009. A Complete Skeleton of a Late Triassic Saurischian and the Early Evolution of Dinosaurs. Science, 326:1530-1533. doi:10.1126/science.1180350

Novas, F.E. 1993. New information on the systematics and postcranial skeleton of Herrerasaurus ischigualastensis (Theropoda: Herrerasauridae) from the Ischigualasto Formation (Upper Triassic) of Argentina. Journal of Vertebrate Paleontology, 13:400-423. doi:10.1080/02724634.1994.10011523

Padian, K. \& Lamm, E.T. 2013. Bone histology of fossil tetrapods. Berkeley, University of California Press, 285 p.

Padian, K.; Ricqlès, A. de \& Horner, J.R. 2001. Dinosaurian growth rates and bird origins. Nature, 412:405-408. doi: $10.1038 / 35086500$

Pol, D. \& Escapa, I.H. 2009. Unstable taxa in cladistic analysis: Identification and the assessment of relevant characters. Cladistics, 25:515-527. doi:10.1111/j.1096-0031.2009.00258.x

Pretto, F.A.; Schultz, C.L. \& Langer, M.C. 2015. New dinosaur remains from the Late Triassic of southern Brazil (Candelária Sequence, Hyperodapedon Assemblage Zone). Alcheringa, 39:264-273. doi:10.1080/03115518.2015.994114

Reid, R.E.H. 1996. Bone histology of the Cleveland-Lloyd dinosaurs and of dinosaurs in general, Part I: Introduction to bone tissues. Geology Studies, 41: 25-71. 
Reid, R.E.H. 1997. How dinosaurs grew. In: J.O. Farlow \& M.K. Brett-Surman (eds.) The Complete Dinosaur, Indiana University Press, p. 403-413.

Schultz, C.L.; Scherer, C.M. dos S. \& Barberena, M.C. 2000. Biostratigraphy of southern Brazilian Middle-Upper Triassic. Revista Brasileira de Geociências, 30:495-498.

Sereno, P.C. \& Arcucci, A.B. 1994. Dinosaurian precursors from the Middle Triassic of Argentina: Marasuchus lilloensis, gen. nov. Journal of Vertebrate Paleontology, 14:53-73. doi:10.1080/02 724634.1994.10011538

Sereno, P.C.; Martínez, R.N. \& Alcober, O.A. 2013. Osteology of Eoraptor lunensis (Dinosauria, Sauropodomorpha). Journal of Vertebrate Paleontology, 32:83-179. doi:10.1080/02724634.2 013.820113

Soares, M.B.; Martinelli, A.G. \& Oliveira, T.V. 2014. A new prozostrodontian cynodont (Therapsida) from the Late Triassic Riograndia Assemblage Zone (Santa Maria Supersequence) of Southern Brazil. Anais da Academia Brasileira de Ciências, 86:1673-1691. doi:10.1590/0001-3765201420140455

Soares, M.B.; Schultz, C.L. \& Horn, B.L.D. 2011. New information on Riograndia guaibensis Bonaparte, Ferigolo \& Ribeiro, 2001 (Eucynodontia, Tritheledontidae) from the Late Triassic of southern Brazil: anatomical and biostratigraphic implications. Anais da Academia Brasileira de Ciências, 83:329-54. doi:10.1590/S0001-37652011000100021
Starck, J.M. \& Chinsamy, A. 2002. Bone microstructure and developmental plasticity in birds and other dinosaurs. Journal of Morphology, 254:232-246. doi:10.1002/jmor.10029

Stein, K. \& Langer, M. 2009. The long bone histology of the stem-sauropodomorph Saturnalia tupiniquim, implications for the early evolution of dinosaur bone microstructure. In: ANNUAL MEETING OF THE SOCIETY OF VERTEBRATE PALEONTOLOGY, 69; SYMPOSIUM OF VERTEBRATE PALEONTOLOGY AND COMPARATIVE ANATOMY, 57, 2009. Abstracts, Bristol, p. 185A.

Weishampel, D.B.; Dodson, P. \& Osmólska, H. 2004. Introduction. In: D.B. Weishampel; P. Dodson \& H. Osmólska (eds.) The Dinosauria, University of California Press, p. 1-3.

Zerfass, H.; Lavina, E.L.; Schultz, C.L.; Garcia, A.J.V.; Faccini, U.F. \& Chemale, F. 2003. Sequence stratigraphy of continental Triassic strata of Southernmost Brazil: a contribution to Southwestern Gondwana palaeogeography and palaeoclimate. Sedimentary Geology, 161:85-105. doi:10.1016/S00370738(02)00397-4

Received in December, 2015; accepted in October, 2016.

Appendix 1. Scoring of MMACR-PV-028-T in the dataset of Bittencourt et al. (2014).

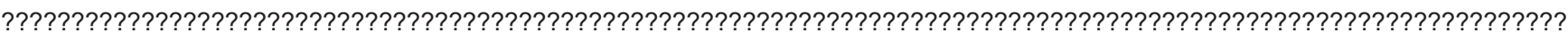

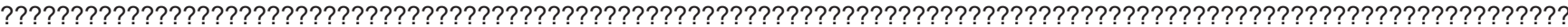

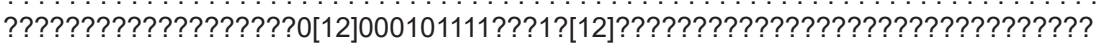

